\title{
VIABILITY AND INFECTIVITY OF AN ECTOMYCORRHIZAL INOCULUM PRODUCED IN AN AIRLIFT BIOREACTOR AND IMMOBILIZED IN CALCIUM ALGINATE
}

\author{
Leyza Paloschi de Oliveira ${ }^{1}$; Márcio José Rossi²; Agenor Furigo Júnior² ; Germano Nunes Silva Filho³; \\ Vetúria Lopes de Oliveira ${ }^{3 *}$
}

${ }^{1}$ Universidade do Contestado, Campus de Caçador, Caçador, SC, Brasil; ${ }^{2}$ Departamento de Engenharia Química e Engenharia de Alimentos, Centro Tecnológico; ${ }^{3}$ Departamento de Microbiologia e Parasitologia, Centro de Ciências Biológicas, Universidade Federal de Santa Catarina, Florianópolis, SC, Brasil

Submitted: August 12, 2004; Returned to authors for corrections: February 10, 2005; Approved: May 06, 2006

\begin{abstract}
The viability and infectivity of an ectomycorrhizal inoculum (isolate UFSC-Rh90, Rhizopogon nigrescens), produced by submerged cultivation in an airlift bioreactor and immobilized in beads of calcium alginate gel, was studied. Inoculum remained $100 \%$ viable after 18 months in a $0.85 \% \mathrm{NaCl}$ solution at $8 \pm 1^{\circ} \mathrm{C}$. Mycelium grew from the beads after $48 \mathrm{~h}$ when they were placed on a solid culture medium at $25 \pm 1^{\circ} \mathrm{C}$. Viability of pellets of non-immobilized mycelium stored under the same conditions decreased gradually after the third month of storage, reaching $0 \%$ by the 12 th month. These pellets presented a gradual darkening, which was more intense in those located near the surface of the $\mathrm{NaCl}$ solution. In culture medium, these dark pellets showed no viability. Gel immobilization helps to maintain mycelium viability during storage and offers a physical protection when the inoculum is applied to the planting substrate. After eight months refrigeration, the immobilized inoculum was still able to infect Pinus taeda seedlings, colonizing an average of $37 \%$ of the root tips when inoculated in the plant growth substrate under greenhouse conditions. This inoculum presents a commercial potential to be produced and applied in forest nurseries.
\end{abstract}

Key words: Rhizopogon nigrescens, ectomycorrhizal fungus, submerged cultivation, Pinus taeda

\section{INTRODUCTION}

The productivity of certain woody plants may be improved by the inoculation with ectomycorrhizal fungi. Though these fungi occur naturally in many forest plantations they differ in their capacity of colonizing roots and improving plant growth. These differences have to be quantified in order to select the best fungus-host combinations. This procedure has been called by Garbaye (3) 'the mycorrhization control'.

Mycorrhization control begins with the isolation and selection of the more efficient fungal isolates to promote plant growth and culminates with the fungal inoculum production $(4,9,14)$. The importance of this management strategy becomes evident if one considers that the most important plants in forestation programmes in Brazil, Eucalyptus spp. and Pinus spp., depend on ectomycorrhizal symbioses in order to survive and grow in natural conditions. Several authors in different countries have reported a significant increase in plant survival and forest productivity by the use of mycorrhization control practices $(4,9)$. However, to achieve mycorrhization control, it is necessary to develop inoculum production methods, which in itself represents a great challenge.

Mycelial inoculum, also known as vegetative inoculum, is produced from fungal pure cultures and is the most recommended type of inoculum, since it allows the selection of the isolates before their application in nurseries. Techniques recently developed employ submerged cultivation procedures followed by immobilization in calcium alginate gel. Inocula produced by these techniques were efficient in colonizing and promoting the growth of different plant species $(5,6,10)$.

*Corresponding Author. Mailing address: Departamento de Microbiologia e Parasitologia, Centro de Ciências Biológicas, Universidade Federal de Santa Catarina, Caixa Postal 476. 88040-900, Florianópolis, SC, Brasil. E-mail: veturia@ccb.ufsc.br 
Immobilized mycelium can survive longer in the soil, is easily stored, and shows greater viability than non-immobilized inoculum $(4,6)$. However, the technique still has limited application due to constraints related to the cultivation in conventional bioreactors, which may compromise the quality of the inocula in a large scale production system (14).

The utilization of airlift bioreactors for ectomycorrhizal fungi cultivation is a new promising technology $(12,13)$. After selecting efficient ectomycorrhizal isolates (17), studies on fungal biomass production by submerged cultivation in airlift bioreactors are being undertaken in order to obtain a high quality and low cost inocula that remains viable for long time, allowing the storage and commercial application of the product.

The objective of this study was to evaluate the viability, in relation to duration of storage, and the infectivity of an ectomycorrhizal inoculum produced by submerged cultivation in an airlift bioreactor, and immobilized in calcium alginate gel.

\section{MATERIALS AND METHODS}

\section{Ectomycorrhizal isolate}

The isolate UFSC-Rh90, Rhizopogon nigrescens Coker e Couch, obtained from a Pinus taeda plantation in Santa Catarina State, southern Brazil, was maintained at $25 \pm 1^{\circ} \mathrm{C}$ on solid MMN medium (Modified Melin-Norkrans) (8), subculturing every two months to fresh medium.

\section{Inoculum production by submerged fermentation in an airlift bioreactor}

Fungal inoculum was produced in an airlift bioreactor using a modified Pridham-Gottlieb $\left(\mathrm{PG}_{\mathrm{M}}\right)$ medium $(12,13)$, and then immobilized in calcium alginate gel (10).

A mycelium suspension was produced from 20-day old cultures in $25 \mathrm{~mL}$ of liquid $\mathrm{PG}_{\mathrm{M}}$ incubated at $25 \pm 1^{\circ} \mathrm{C}$. Afterwards, mycelium was fragmented in a stirring blender and the resulting suspension was employed to inoculate the bioreactor.

A volume of $2.3 \mathrm{~L}$ of the $\mathrm{PG}_{\mathrm{M}}$ medium was sterilized at $121^{\circ} \mathrm{C}$ for $20 \mathrm{~min}$ and inoculated with the mycelial suspension ( $c a .0 .25$ g mycelium $\mathrm{L}^{-1}$ ) from liquid cultures. This inoculated medium was then transferred to the bioreactor through sterilized connections. Fermentation took place at $25 \pm 1{ }^{\circ} \mathrm{C}$ in an airlift borosilicate glass bioreactor with a specific air flow rate of 0.4 vvm (air volume per volume of culture medium per minute). Air was sterilized by filtration through a Millipore ${ }^{\circledR}$ membrane with a pore diameter of $0.2 \mu \mathrm{m}$.

\section{Mycelium immobilization in calcium alginate gel and viability test}

Mycelium produced in the airlift bioreactor was removed aseptically and washed with sterile distilled water. Afterwards the mycelium was kept in saline solution $(0.85 \% \mathrm{NaCl})$ at $8 \pm$ $1^{\circ} \mathrm{C}$. Three samples of $1 \mathrm{~mL}$ were transferred to solid MMN medium in Petri dishes and incubated at $25 \pm 1^{\circ} \mathrm{C}$ to determine the initial viability of the mycelium. Two days latter, after confirming the viability of the mycelium, a portion $(c a .9 \mathrm{~g}$ of fresh mycelium) was immobilized in calcium alginate gel (10). The non-immobilized portion of the mycelium was also stored in saline solution $(0.85 \% \mathrm{NaCl})$ at $8 \pm 1^{\circ} \mathrm{C}$ and tested for viability as described bellow for the immobilized inoculum.

The mycelium was prepared for immobilization by fragmenting it during 6-7 s in a blender at 3,600 rpm in $150 \mathrm{~mL}$ of sterilized distilled water. The mycelium suspension was mixed with an equal volume of a sterilized sodium alginate solution (2\%). This mixture was then dripped into a $0.7 \mathrm{M}$ $\mathrm{CaCl}_{2} \cdot 2 \mathrm{H}_{2} \mathrm{O}$ solution under mechanical shaking in order to achieve polimerization and formation of $4 \mathrm{~mm}$-diameter calcium alginate beads. The entire operation was performed at room temperature. After complete polimerization, during 40 to 50 min, beads were washed in sterilized distilled water to eliminate chloride residues and stored at $8 \pm 1^{\circ} \mathrm{C}$. Every 30 days, for 18 months, two portions of 25 beads were tested for inoculum viability by placing them on solid MMN medium in Petri dishes and incubating at $25 \pm 1^{\circ} \mathrm{C}$.

\section{Infectivity of the immobilized inoculum towards Pinus taeda seedlings under greenhouse conditions}

After 8 months storage, the infectivity of the immobilized inoculum towards Pinus taeda seedlings was evaluated under greenhouse conditions.

Planting substrate was prepared with a mixture of peat:vermiculite $(30: 70, \mathrm{v} / \mathrm{v})$ and distributed in conical $60 \mathrm{~mL}$ PVC pots. These pots had been previously disinfected with a $2 \%$ sodium hypochloride solution. Substrate was sterilized twice at $121^{\circ} \mathrm{C}$, for $60 \mathrm{~min}$, within a $24 \mathrm{~h}$ period. To each pot was added $0.25 \mathrm{~g}$ of Osmocote ${ }^{\circledR}(14-8-8, \mathrm{~N}-\mathrm{P}-\mathrm{K})$, or $0.020 \mathrm{~g}$ of Nutricote $^{\circledR}$ (18-5-9, NPK) (1). Osmocote and Nutricote are the most utilized fertilizers by seedlings producers in Santa Catarina state.

Before sowing, $P$. taeda seeds were submitted to a dormancy break treatment at $4^{\circ} \mathrm{C}$ for 180 days. Inoculation was performed during the sowing, using 4 beads per pot. The viability of the mycelium in the beads was previously confirmed in a sample of 100 beads after 2 days of cultivation in solid MMN medium at $25 \pm 1^{\circ} \mathrm{C}$. Non-inoculated control pots received the same amount of calcium alginate beads without any mycelium. The experiment presented a completely random design with a factorial arrangement - 2 fertilizers $x 2$ inoculation levels (inoculated and non-inoculated) - with five replications per treatment. Plants were kept at $25 \pm 1^{\circ} \mathrm{C}$ in a greenhouse, and watered every day with distilled water.

After 6 months, plants were harvested and root systems were examined under a binocular microscope (10-30X) to estimate the percentage of mycorrhizal colonization. A sample of 500 root tips was examined per plant. Numbers of colonized root tips in these samples were used to calculate the percentage of 
colonization. Besides the presence of a conspicuous fungal sheath and external mycelial strands and rhizomorphs, the mycorrhizal nature of the root tips was confirmed in transversal root microtomed sections $(20 \mathrm{~mm})$, cut with a cryomicrotome and observed under an optical microscope (400 X).

Data were submitted to variance analysis and averages compared by the Tukey test $(\mathrm{p} \leq 0.05)$. Before analysis, data of percentage of mycorrhizal colonization were transformed using $\arcsin \sqrt{\% \text { colonization }+0.5 / 100}$.

\section{RESULTS AND DISCUSSION}

\section{Viability of the immobilized inoculum}

Mycelium of the fungus $R$. nigrescens immobilized in calcium alginate gel presented $100 \%$ of viability after 18 months of storage under refrigeration (Figs. 1 and 2). Pellets of the nonimmobilized mycelium, stored under the same conditions in saline solution, showed a gradual darkening, which was more intense in the areas more exposed to the flask atmosphere. In culture medium, these pellets exhibited a partial and gradual loss of viability, possibly due to a toxic action of oxidized phenolics (18). This observation demonstrates an advantage of immobilizing the mycelium: besides the physical protection and humidity retention when applied to the planting substrate, mycelium is already protected during the storage period. Furthermore, immobilization in alginate gel allows the addition of other protectors such as active charcoal for the adsorption

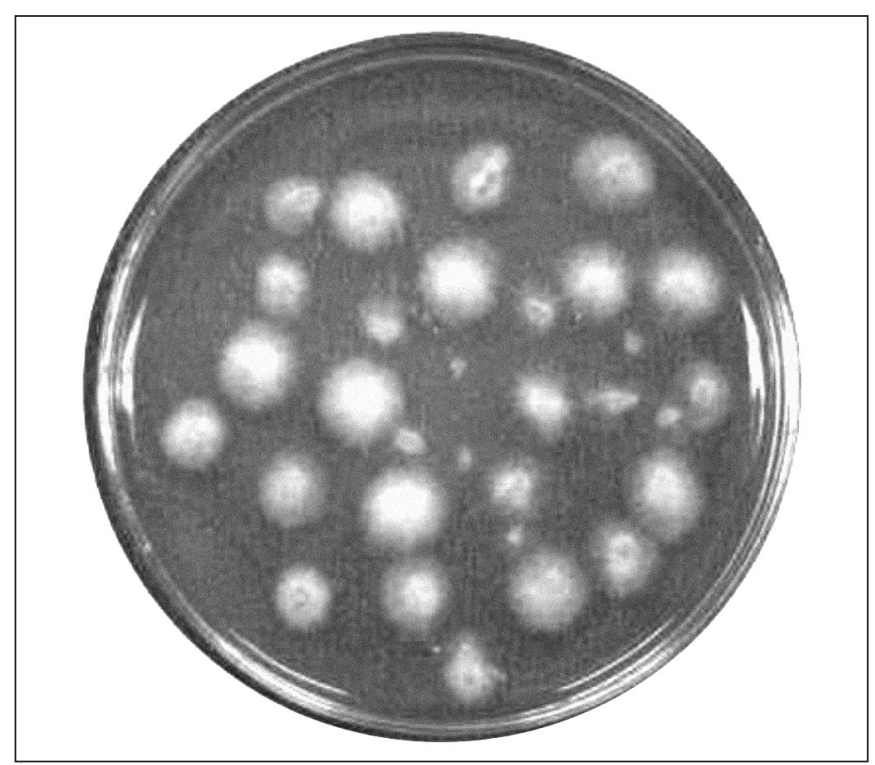

Figure 1. General view of 18 month-old alginate beads of immobilized mycelium of Rhizopogon nigrescens UFSC-Rh90 growing on the surface of MMN agar after $48 \mathrm{~h}$ incubation at $25 \pm 1^{\circ} \mathrm{C}$.

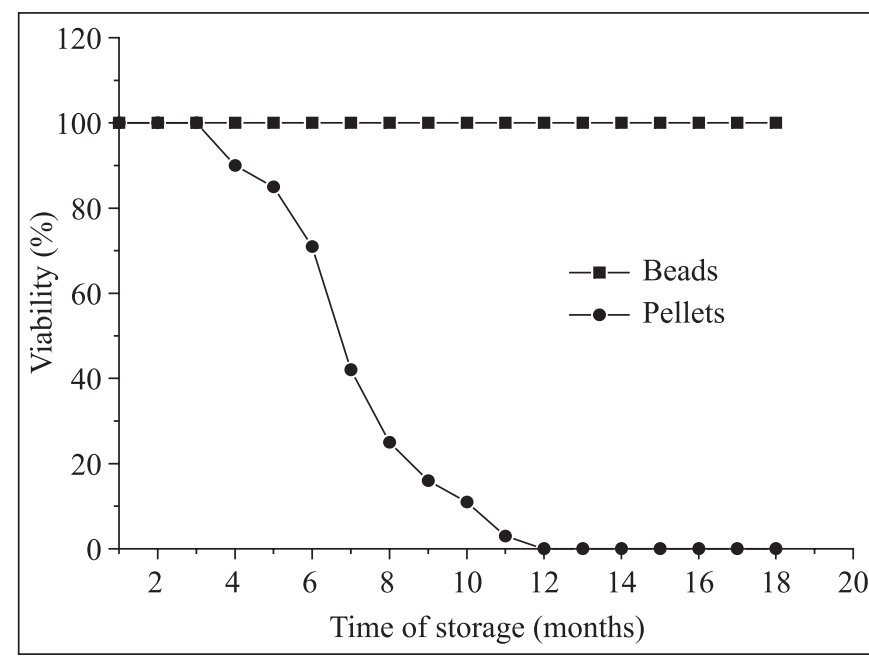

Figure 2. Viability of the ectomycorrhizal inoculum (Rhizopogon nigrescens UFSC-Rh90) produced by submerged cultivation in an airlift bioreactor and immobilized in calcium alginate gel beads (ם), compared to pellets of the non-immobilized inoculum of the same isolate $(\bigcirc)$, in relation to the storage period at $8 \pm 1^{\circ} \mathrm{C}$.

of toxic compounds in the soil or produced by the fungus itself. Immobilization may also protect the mycelium against many soil antagonists assuring its viability until receptive roots are produced by the plant host (4).

Employing the same technique of mycelium immobilization, Rodrigues et al. (11), observed $100 \%$ of viability with the fungus Paxillus involutus, and less than $60 \%$ for Pisolithus tinctorius, after 60 days storage, both cultivated in liquid medium in static flasks. Maupérin et al. (10) also observed a high viability for the immobilized inoculum of Hebeloma crustuliniforme after 5 months under refrigeration. These authors suggested that the inoculum could tolerate at least 10 months under this storage conditions. According to Kuek et al. (6), depending upon the fungal species, this technique of inoculum production could maintain mycelium viable for periods longer than 7 months. The results obtained in the present study show that it is possible to keep inoculum viability for a much longer time (Fig. 2).

Nevertheless, it is not surprising that different species of ectomycorrhizal fungi present different survival rates when submitted to the immobilization technique. These fungi are found in different phyla of the Kingdom Fungi, and may present significant differences in terms of metabolical and physiological characteristics (15).

\section{Infectivity of the immobilized inoculum towards Pinus taeda seedlings under greenhouse conditions}

After 8 months of storage, immobilized inoculum of Rhizopogon nigrescens presented a significant root infectivity when added to planting substrate of Pinus taeda seedlings 
(Table 1). Root colonization presented an average of 37\%, with $35 \%$ and $39 \%$ colonization for the 14-8-8 and 18-5-9 treatments, respectively. These values are comparable to the colonization rates observed by other authors in mycorrhization control programmes employing other types of inoculum $(1,2,16,19)$.

These results demonstrated that it is possible to maintain the viability and the infectivity of an ectomycorrhizal inoculum during a long period of refrigeration by the immobilization of the mycelium in calcium alginate gel. These results corroborate observations made by other authors in relation to the advantage of mycelium immobilization $(7,10)$. This advantage lies not only on the facilities offered to storing and transporting the inoculum, but also on the high survival rate and infectivity by longer periods.

According to the results, the inoculum of the isolate UFSC$\mathrm{Rh} 90$, produced by submerged cultivation in an airlift bioreactor and immobilized in calcium alginate gel, displays a high survival rate under refrigeration, with $100 \%$ viability after 18 months. This inoculum also presented a significant infectivity in relation to Pinus taeda seedlings after 8 months of storage, which indicate a high potential for the commercial application of the inoculum in forest nurseries. However, it is necessary to determine the efficiency of the inoculum in promoting plant growth as well as the applicability of the production method to other ectomycorrhizal fungi.

Table 1. Mycorrhizal colonization of Pinus taeda seedlings, inoculated with the ectomycorrhizal isolate Rhizopogon nigrescens UFSC-Rh90 cultivated in an airlift bioreactor and immobilized in a calcium alginate gel and stored during 8 months at $8^{\circ} \mathrm{C}$, after 180 days in greenhouse.

\begin{tabular}{cccc}
\hline & \multicolumn{3}{c}{ \% root colonization* } \\
\cline { 2 - 4 } Fertilizer & $\begin{array}{c}\text { Non-inoculated } \\
\text { control }\end{array}$ & UFSC-Rh90 & Average \\
\hline $14-8-8$ & 0 & 35 & $17 \boldsymbol{A}$ \\
$18-5-9$ & 0 & 39 & $20 \boldsymbol{A}$ \\
Average & $0 \boldsymbol{b}$ & $37 \boldsymbol{a}$ & \\
\hline
\end{tabular}

*Values represent the average of 5 replications. Those followed by different letters are significantly different according to Tukey's test $(\mathrm{p} \leq 0.05)$.

\section{ACKNOWLEDGEMENTS}

The authors gratefully acknowledge the "Empresa de Pesquisa Agropecuária do Estado de Santa Catarina (EPAGRI) - Estação Experimental de Caçador" for facilities; the "Fundação de Ciência e Tecnologia do Estado de Santa Catarina (FUNCITEC)" for funding this research; and Dr. Geoff Carr, London, UK for reviewing this manuscript.

\section{RESUMO \\ Viabilidade e infectividade de inoculante ectomicorrízico produzido em biorreator airlift e encapsulado em algianto de cálcio}

Estudou-se a viabilidade e a infectividade de inoculante fúngico ectomicorrízico (isolado UFSC-Rh90, Rhizopogon nigrescens), produzido através de cultivo submerso em biorreator airlift e encapsulado em gel de alginato de cálcio. $\mathrm{O}$ inoculante permaneceu viável após 18 meses em solução de $\mathrm{NaCl}(0,85 \%)$ a $8 \pm 1^{\circ} \mathrm{C}$. O micélio emergiu dessas cápsulas após $48 \mathrm{~h}$ de incubação a $25 \pm 1^{\circ} \mathrm{C}$ em meio de cultura sólido. A viabilidade dos pellets de micélio não imobilizado, armazenados sob as mesmas condições, reduziu-se gradualmente após três meses de armazenamento e atingiu 0\% aos 12 meses. Esses pellets apresentaram um escurecimento gradual que foi mais intenso naqueles localizados próximos à superfície da solução de $\mathrm{NaCl}$. Em meio de cultura, os pellets escurecidos mostraramse inviáveis. A imobilização em gel mantém a viabilidade do micélio durante o armazenamento, além de oferecer uma barreira física quando aplicado ao substrato de plantio. Após oito meses de armazenamento sob refrigeração, o inoculante imobilizado colonizou uma média de $37 \%$ das raízes curtas de mudas de Pinus taeda, quando aplicado ao substrato de plantio sob condições de casa-de-vegetação. Esse inoculante apresenta potencial para produção comercial e aplicação nos viveiros florestais.

Palavras-chave: Rhizopogon nigrescens, fungo ectomicorrízico, cultivo submerso, Pinus taeda

\section{REFERENCES}

1. Alves, J.R.; Souza, O.; Podlech, P.A.S.; Giachini, A.J.; Oliveira, V.L. Efeito de inoculante ectomicorrízico produzido por fermentação semi-sólida no crescimento de Eucalyptus dunnii Maiden. Pesq. Agropec. Bras., 36, 307-313, 2001.

2. Bougher, N.L.; Grove, T.S.; Malajczuk, N. Growth and phosphorus acquisition of karri (Eucalyptus diversicolor B. Muell.) seedlings inoculated with ectomycorrhizal fungi in relation to phosphorus supply. New Phytol., 114, 77-85, 1990.

3. Garbaye, J. First results of research on the competitivity of ectomycorrhizal fungi. Plant Soil, 71, 303-308, 1983.

4. Garbaye, J. Utilisation des mycorhizes en sylviculture. In: Strullu, D.G. (ed.), Les mycorhizes des arbres et plantes cultivées. Lavoisier, Paris, 1990. p.197-250.

5. Kropácek, K.; Cudlín, P.; Mejstrík, V. The use of granulated ectomycorrhizal inoculum for resforestation of deteriorated regions. Agric. Ecosystems Environ., 28, 263-269, 1990.

6. Kuek, C.; Tommerup, I.C.; Malajczuck, N. Hydrogel bead inocula for the production of ectomycorhizal eucalyptus for plantations. Mycol. Res., 96, 73-77, 1992.

7. Le Tacon, F.; Jung, G.; Mugnier, J.; Michelot, P.; Maupérin, C. Efficiency in a forest nursery of an ectomycorrhizal fungus inoculum produced in a fermentor and entrapped in polymeric gels. Can. J. Bot., 63, 1664-1668, 1985. 
8. Marx, D.H. The influence of ectotrophic mycorrhizal fungi on the resistence of pine roots to pathogenic fungi and soil bacteria. Phytopathol., 59, 153-163, 1969.

9. Marx, D.H.; Bryan, W.C.; Cordell, C.E. Survival and growth of pine seedlings with Pisolithus ectomycorrhizae after two years on reforestation sites in North Caroline and Florida. For. Sci., 23, 363373, 1977

10. Maupérin, Ch.; Mortier, F.; Garbaye, J.; Le Tacon, F.; Carr, G. Viability of an ectomycorrhizal inoculum produced in a liquid medium and entrapped in a calcium alginate gel. Can. J. Bot., 65, 2326-2329, 1987.

11. Rodrigues, L.S.; Kasuya, M.C.M.; Borges, A.C. Viability of ectomycorrhizal fungus mycelium entrapped in calcium alginate gel. Mycorrhiza, 8, 263-266, 1999.

12. Rossi, M.J. Produção de inoculante de fungo ectomicorrízico utilizando fermentação no estado líquido em biorreator airlift. Florianópolis, 2001. 93p. (M.Sc. Thesis. Universidade Federal de Santa Catarina).
13. Rossi, M.J.; Souza, J.A.R.; Oliveira, V. Inoculum production of the ectomycorrhizal fungus Pisolithus microcarpus in an airlift bioreactor. Appl. Microbiol. Biot., 59, 175-181, 2002.

14. Šašek, V. Submerged cultivation of ectomycorrhizal fungi. Agric. Ecosystems Environ., 28, 441-447, 1990.

15. Smith, S.E.; Read, D.J. Mycorrhizal symbiosis. Academic Press, London, 1997. 605p.

16. Soares, I.; Borges, A.C.; Barros, N.F.; Bellei, M.M. Níveis de fósforo na formação de ectomicorrizas em mudas de eucalipto. Rev. Bras. Ciência Solo, 14, 327-332, 1990.

17. Souza, L.A.B.; Silva Filho, G.N.; Oliveira, V.L. Eficiência de fungos ectomicorrízicos na absorção de fósforo e na promoção do crescimento de eucalipto. Pesq. Agropec. Bras., 39, 349-355, 2004.

18. Suh, H.-W.; Crawford, D.L.; Korus, R.A.; Shetty, K. Production of antifungal metabolites by the ectomycorrhizal fungus Pisolithus tinctorius strain SMF. J. Ind. Microbiol., 8, 29-36, 1991.

19. Walker, R.F. Growth and nutricional responses of containerized sugar and Jeffrey pine seedlings to controlled release fertilization and induced mycorrhization. For. Ecol. Manage., 149, 103-179, 2001. 